\title{
Principled Silence or Mere Silence on Principles? The Role of the EU Charter's Principles in the Case Law of the Court of Justice
}

\author{
Jasper Krommendijk*
}

\begin{abstract}
Historical background of the inclusion of social rights in the Charter of Fundamental Rights - Distinction between rights and principles - Similarities between the conditions for direct effect and the criteria for distinguishing between Charter rights and principles - Implications of this distinction for the possibilities of judicial review - Reluctance of the ECJ to explicitly deal with the distinction until Glatzel, as illustrated by its earlier judgments in Dominguez and AMS.
\end{abstract}

\section{INTRODUCTION}

One of the most contentious issues to arise during the negotiations on the EU Charter of Fundamental Rights in 2000 and its 'incorporation' in the Constitutional and Lisbon Treaties was the inclusion of social rights in the Charter. On the one hand, various EU member states and commentators favoured the inclusion of social rights to address the social deficit of an EU which primarily championed economic freedoms. On the other hand, several states - especially the UK - fervently opposed the inclusion of such 'costly' and aspirational (social) rights. The disagreement was eventually overcome by inserting a distinction between 'rights' and 'principles' in the Charter. Article 51(1) provides that EU institutions and bodies as well as member states 'shall therefore respect the rights, observe the principles and promote the application thereof, while Article 52(5) stipulates that principles 'shall be judicially cognisable only in the interpretation of such acts and in the ruling on their legality.' As will be argued in this article, the difference between rights and principles in the Charter is not very evident.

*Assistant professor of EU law, Radboud University Nijmegen. I would like to thank Dr Katarina Eisele, Prof Janneke Gerards, Dr John Morijn, Dr Elise Muir and Prof Henri de Waele as well as the peer reviewers for their valuable comments on earlier versions of this article. Any errors obviously remain the sole responsibility of the author. 
The Charter itself does not make a clear distinction. Because member states could not arrive at a list that categorised each and every provision, the decision was made to leave it to the Court of Justice to clarify the nature of the Charter's provisions on a case-by-case basis. This article will examine whether the Court of Justice has indeed taken up this task. More specifically, it addresses the question of to what extent the Court has made this distinction between rights and principles in its case law after the entry into force of the Lisbon Treaty and how it has assessed the distinction's implications for judicial review.

This question is not solely of theoretical interest. A Charter provision's character has implications for the possibilities for individuals to invoke it before courts. As the quoted part of Article 52(5) shows, principles were meant to have a more limited justiciability than rights. Hence, if the Court of Justice casts the net too wide and interprets many provisions as rights, this could lead to - in the words of critics - a juridification of politics, whereby individuals have ample opportunities to challenge - democratically legitimised - EU and national acts and measures. These fears are not completely unfounded, as some have argued, because the Court has shown in the past that it is not afraid of interpreting EU law in a dynamic and progressive way. A too-broad interpretation could hence result in an ever more expansive EU fundamental rights system with all concomitant problems. ${ }^{1}$ On the other hand, if the Court is too restrictive in its approach, i.e. by categorising many provisions as mere principles and interpreting the possibilities for judicial review narrowly, it could leave many individuals with empty hands and without an effective judicial remedy. This is especially pertinent nowadays in times of economic crisis and austerity measures.

This article discusses several recent cases in which the Court of Justice dealt with - or could have dealt with - the distinction between rights and principles. ${ }^{2}$ These include Dominguez ${ }^{3}$ (Article 31(1) of the Charter on the right to paid annual leave), Kamberaj ${ }^{4}$ (Article 34(3) on the right to housing assistance), $A M S^{5}$ (Article 27 on the worker's right to information and consultation within the undertaking), Pohotovost ${ }^{6}$ (Article 38 on consumer protection) and Glatzel $^{7}$ (Article 26 on the

${ }^{1}$ L. Burgorgue-Larsen, 'Article II-112' in Burgorgue-Larsen et al. (eds.), Traité établissant une Constitution pour l'Europe Partie II. La Charte des droits fondamentaux de l'Union. Commentaire article par article (Bruylant 2005) p. 687.

${ }^{2}$ These cases were selected because the distinction between rights and principles played a role in the Opinion of the A.G. (Dominguez, AMS and Pohotovost) or the judgment of the ECJ (Glatzel). Kamberaj was included because several scholars noted that the provision at play, Art. 34(3), is most likely a principle. See n. 128 infra.

${ }^{3}$ ECJ 24 January 2012, Case C-282/10, Dominguez.

${ }^{4}$ ECJ 24 April 2012, Case C-571/10, Kamberaj.

${ }^{5}$ ECJ 15 January, Case C-176/12, AMS.

${ }^{6}$ ECJ 27 February 2014, Case C-470/12, Pohotovost's.r.o. v Miroslaw Vašuta.

${ }^{7}$ ECJ 22 May 2014, Case C-356/12, Glatzel. 
integration of persons with disabilities). These cases are analysed in the light of the following questions: in what way has the distinction between rights and principles played a role in these cases and what criteria have been used by the Court or the Advocate General to make such a distinction? And what has been the implication of this (lack of) distinction for the review the Court of Justice has conducted (or has not conducted)?

Before addressing these questions, the second section provides a historical background to the inclusion of social rights in the Charter. It elaborates on the debates on and reasons for the introduction of the distinction between rights and principles. This introductory overview aims to illustrate why the distinction is such a controversial issue and why it is important for the Court of Justice to take into account. The third section briefly examines the distinction between Charter principles and other EU principles, most notably general principles of law, as well as their relation with social rights. The fourth section discusses how the Charter and its Explanations ${ }^{8}$ distinguish between rights and principles. Section five reflects on the implications of this distinction for the possibility of judicial review. Then, Section six turns to the analysis of case law in order to answer the central question of this article.

\section{BACKground AND GENESIS OF SOCIAL RIGHTS IN THE CHARTER}

The inclusion of principles in the Charter has its origin in the growing concerns in the 1980s about the potential negative implication for social standards and wages arising out of the Single European Market and the increased competition between member states. There were increasing requests to give a 'social dimension' to the European Economic Community in order to prevent a 'race to the bottom' with respect to social and labour standards. ' These developments led to the adoption of the 1989 Community Charter of the Fundamental Social Rights of Workers which included several social rights of workers as well as obligations for member states to realise certain objectives related to social policy and labour law. ${ }^{10}$ Because this Charter was - as stated in the preamble - only a political declaration, calls to draft a legally binding document continued. The 1996 report of the Comité des

${ }^{8}$ O.J. 2007, C 303/32. The Explanations do not have the 'status of law', but they are a 'valuable tool of interpretation' as the preamble of the Charter makes clear as well. Art. 6(1), third sentence TFEU furthermore provides: 'The rights, freedoms and principles in the Charter shall be interpreted [...] with due regard to the explanations referred to in the Charter.' See also Art. 52(7) of the Charter.

${ }^{9}$ For a description of the history of social rights in the EU, see J. Kenner, 'Economic and Social Rights in the EU Legal Order: the Mirage of Indivisibility', in T.K. Hervey and J. Kenner (eds.), Economic and Social Rights under the EU Charter of Fundamental Rights: a Legal Perspective (Hart 2003) p. 1 at p. $7-15$.

${ }^{10}$ O.J. 1989, C 323/44. 
Sages, For a Europe of Civic and Social Rights, for instance, urged the adoption of a 'bill of rights' which would include both 'civic and social rights'. ${ }^{11}$ The Cologne European Council of June 1999 eventually decided to establish a charter which would incorporate both categories. The Council noted in particular that: 'In drawing up such a Charter, account should furthermore be taken of economic and social rights as contained in the European Social Charter and the Community Charter of the Fundamental Social Rights of Workers (Article 136 TEC), insofar as they do not merely establish objectives for action by the Union' (emphasis added). ${ }^{12}$ Especially the last part of the Council's 'task' led to conflicting interpretations during the drafting of the Charter by the First Convention, which took place between December 1999 and the fall of 2000. ${ }^{13}$ These conflicting interpretations were essentially based on two diametrically opposed paradigms, which led to lengthy and complex debates. ${ }^{14}$

One group of countries, 'led by' the UK and also including countries like Denmark and the Netherlands, ${ }^{15}$ was opposed to the inclusion of such 'social rights' as legally enforceable claims. ${ }^{16}$ In the words of the UK government's representative on the First Convention, Lord Goldsmith, the UK 'had to fight very hard' in order not to have the Charter include such rights in an overly intrusive way. ${ }^{17}$ Especially the recognition of a right to strike in the Charter

\footnotetext{
${ }^{11}$ Comité des Sages, For a Europe of Civic and Social Rights (Office for Official Publications of the European Communities 1996) p. 6.

${ }^{12} 1999 / 2064$ (COS) - 04/06/1999.

${ }^{13}$ Several of the preparatory documents and NGO contributions can be accessed via the website of the First Convention, <www.europarl.europa.eu/charter/default_en.htm>, visited 3 March 2015.

${ }^{14}$ J.P. Jacqué, 'La Charte des droits fondamentaux de l'Union européenne. Aspects juridiques généraux', 14 ERLP/REDP (2002) p. 107 at p. 112. O. De Schutter, 'La garantie des droits et principes sociaux dans la Charte des droits fondamentaux de l'Union Européenne', in J. Carlier and O. De Schutter (eds.), La Charte des droits fondamentaux de l'Union. Son apport à la protection des droits de l'homme en Europe (Bruylant 2002) p. 117 at p. 118.

${ }^{15}$ For an overview of the Dutch reservations towards social rights more generally, see J. Krommendijk, The domestic impact and effectiveness of the process of state reporting under UN human rights treaties in the Netherlands, New Zealand and Finland. Paper pushing or policy prompting? (Intersentia 2014) p. 154-158.

${ }^{16} \mathrm{G}$. Braibant, La Charte des droits fondamentaux de l'Union européenne. Témoignage et commentaires (Seuil 2001) p. 252. Burgorgue-Larsen, supra n. 1, p. 683. S. Prechal, 'Rights v. principles, or how to remove fundamental rights from the jurisdiction of the courts', in J.W. De Zwaan et al. (eds.), The European Union: An ongoing process of integration - Liber amicorum Alfred E. Kellerman (Asser Press 2004) p. 177 at p. 178-179.

${ }^{17}$ Lord Goldsmith QC, 'A charter of rights, freedoms and principles', 38 CML Rev. (2001) p. 1206 at p. 1212-1213. Jacqué, supra n. 14, p. 112-113. UK representative on the Second Convention, Peter Hain, likewise argued that the inclusion of social rights could result in the UK's 'domestic legislation being disregarded on social matters'. A.G. Menéndez, 'The sinews of peace:
} 
(currently Article 28) was opposed from the beginning by the UK. ${ }^{18}$ This was based on the idea that the inclusion of such a right and other social rights would be 'deeply damaging' for the British economy because it would 'put jobs at risk and open the floodgates to a rash of potentially costly legal challenges'. ${ }^{19}$ The UK therefore preferred to treat social rights as mere programmatic or aspirational ${ }^{20}$ objectives which should be guaranteed by the legislature instead of courts. ${ }^{21}$ Underlying this point of view is the idea that social rights or principles would solely require intervention or positive action on the part of the state, whereas civil and political rights actually protect the individual against a state. UK representative Lord Goldsmith, for example, argued that social and economic rights 'are usually not justiciable individually in the same way as other rights'. ${ }^{22}$ This reflects a reluctance to have the judiciary decide on such broad issues because of a lack of expertise among judges, but also, and above all, because of the idea that such decisions should be made by democratically elected governments and parliament. There was, further, a fear that such social rights or principles would lead to legal claims with considerable financial implications. ${ }^{23}$ Moreover, it was considered that that the inclusion of social rights could lead to an unwarranted extension of EU powers and competences in the field of social and economic policy. $^{24}$

The second view was primarily expressed by lawyers from the civil law tradition and left-wing politicians who negated the distinction between 'civil rights' and 'social rights' or downplayed the importance of this distinction. ${ }^{25}$ Especially the French and Spanish governments were keen on including 'social rights' in the

rights to solidarity in the Charter of Fundamental Rights of the European Union', 16 Ratio Juris (2003) p. 373 at p. 393.

${ }^{18}$ Braibant, supra n. 16 , p. 46.

${ }^{19}$ The Times, 1 June 2000 , p. 4.

${ }^{20}$ The UK representative during the Second Convention, Rt Hon Baroness Scotland of Asthal, referred to the 'aspirational character' of principles; Working Group II, WD 16, 13 September 2002 , p. 4.

${ }^{21}$ This argument was already visible in the defence of the UK in Defrenne II dealing with equal pay (Art. 159 TFEU, ex 119 EEC). The UK argued that 'such a 'general statement of principle' primarily requires legislative action on the part of the Member States'; ECJ, 8 April 1976, Case C-43/75, Defrenne v Sabena, p. 459-460.

${ }^{22}$ Goldsmith, supra n. 17, p. 1212.

${ }^{23}$ UK representative during the Second Convention, Rt Hon Baroness Scotland of Asthal, for example, regretted Art. 31(2) of the Charter because of its impact on national politics and finance. S. Koukoulis-Spiliotopoulos, 'Les droits sociaux: droits proclamés ou droits invocables? Un appel à la vigilance', in B. Favreau (ed.), La Charte des droits fondamentaux de l'Union européenne après le traité de Lisbonne (Bruylant 2010) p. 265 at p. 288.

${ }^{24}$ Goldsmith, supra n. 17, p. 1213. Prechal, supra n. 16, p. 179.

${ }^{25}$ C. Ladenburger, 'Artikel 52 Abs. 5', in P.J. Tettinger and K. Stern (eds.), Kölner GemeinschaftsKommentar Europäische Grundrechte-Charta (Verlag C.H. Beck 2006) para 7. 
Charter for this reason. The representative of the French government to the First Convention, Guy Braibant, requested the insertion of several social rights in the Charter because France could not subscribe to a minimal text without them. ${ }^{26}$ He actively championed the idea of a limited justiciability or 'justiciabilité normative' of social rights. ${ }^{27}$ This idea was inspired by jurisprudence of the French Conseil Constitutionnel in which the right of every person to have decent housing was acknowledged. The existence of such a right was based on the recognition of a principle of constitutional value (un objectif de nature constitutionelle) derived from the respect for human dignity. ${ }^{28}$ In the French system, such principles of constitutional value are capable of having an interpretive function and allow for a review of validity of acts. ${ }^{29}$ This idea of justiciabilite normative was at the centre of the joint contribution of Braibant and the German Member of Parliament Meyer, presented as the compromis Braibant-Meyer during the First Convention. ${ }^{30}$ The inclusion of social rights was also influenced by the contribution of the Spanish representative Rodríguez-Bereijo. He proposed a typology of fundamental rights, ordinary rights and policy clauses. ${ }^{31}$ This distinction was based on the Spanish Constitution, with Chapter II on 'rights and liberties' and Chapter III on 'principles governing economic and social policy'. According to Article 53(3) of the Spanish Constitution, such principles 'may only be invoked before the ordinary courts in accordance with the legal provisions implementing them'. ${ }^{32}$

The First Convention eventually agreed to include several 'social rights' in the Charter. The Charter was proclaimed on 7 December 2000 by the Nice European Council. The concerns of the UK and other countries were partly met by not granting the Charter legally binding status. In addition, a distinction between rights and principles was included, based on the above mentioned French idea of justiciabilité normative and the ideas expressed in the Spanish Constitution. The distinction was made clear in the Preamble and in Article 51(1) which stipulated

\footnotetext{
${ }^{26}$ Braibant, supra n. 16, p. 45. Braibant's proposal included the current Articles 27, 28, 31(2), 34(3), 36-38. EU Network of Independent Experts on Fundamental Rights, 'Commentary of the Charter', <ec.europa.eu/justice/fundamental-rights/files/networkcommentaryfinal_en.pdf>, visited 29 October 2014, at p. 405-406.

${ }^{27}$ Braibant, supra n. 16, p. 46.

${ }^{28}$ Burgorgue-Larsen, supra n. 1, p. 684. Jacqué, supra n. 14, p. 114.

${ }^{29}$ A.G. Cruz-Villalón, Opinion 18 July 2013, Case C-176/12, AMS, para 48.

${ }^{30}$ CONTRIB 258/4.7.2000, 'Proposition relative aux droits économiques et sociaux fondamentaux', 13 June 2000, <ec.europa.eu/dorie/fileDownload.do?docId=8807\&cardId=8807>, visited 3 March 2015. Braibant, supra n. 16, p. 45. EU Network, supra n. 26, p. 406.

${ }^{31}$ CHARTE $4414 / 00$ as referred to in Menéndez, supra n. 17, p. 386.

${ }^{32}$ See the general report of Seminar of Association of the Councils of State and Supreme Administrative Jurisdictions held in the Hague on 24 November 2011, <www.aca-europe.eu/ images/media_kit/seminars/DenHaag2011/Gen_Report_en.pdf>, visited 22 July 2014, para E9.
} 
that EU institutions and members states 'shall respect ... rights, observe the principles and promote the application thereof.... 33

The Second Convention was set up in December 2001 on the basis of the Laeken Declaration on the Future of Europe and was entrusted with the task of coming up with a proposal for institutional reforms to make the EU more democratic, transparent and effective. ${ }^{34}$ Discussions quickly focused on drafting a Constitution for the EU as well as on the status of the Charter and its inclusion in EU law. The UK argued that the distinction was unclear and criticised the legal uncertainty created as a result of the lack of assignment of the provisions in the Charter to the two categories. ${ }^{35}$ The UK only agreed with the inclusion of the Charter in the draft Constitution on the condition that the distinction between rights and principles was further clarified. The Working Group II therefore 'confirmed' the distinction by adding Article 52(5) for reasons of 'legal certainty'. ${ }^{36}$ Article 52(5) stipulates that principles 'shall be judicially cognisable only in the interpretation of such acts and in the ruling on their legality.' Several members of the Working Group at the same time quickly added that these additions 'do not reflect modifications of substance', but rather 'confirm, and render absolutely clear and legally watertight, certain key elements' ${ }^{37}$ Be that as it may, the additional clarification in Article 52(5) was an 'important element' or 'indispensable ingredient' which made inclusion of the Charter in the Constitution possible. ${ }^{38}$ Thus, Article 52(5) acted as a 'political lubricant'. ${ }^{39}$

When the Constitution was replaced by the Lisbon Treaty, the UK undertook another attempt together with Poland to emphasise and confirm the distinction by including Article 1(2) in Protocol 30 on the application of the Charter to Poland and to the United Kingdom. This Article stipulates: 'In particular, and for the avoidance of doubt, nothing in Title IV of the Charter creates justiciable rights applicable to Poland or the United Kingdom except in so far as Poland or the United Kingdom have provided for such rights in its national law. ${ }^{40}$

${ }^{33}$ CONV 354/02, 'Final Report of Working Group II', p. 8. C. Ladenburger, 'Protection of Fundamental Rights post-Lisbon', FIDE 2012, <www.fide2012.eu/index.php?doc_id=88>, visited 28 April 2014, p. 31.

${ }^{34}$ Almost all the preparatory and negotiation documents can be accessed via <europeanconvention.europa.eu/>, visited 3 March 2015.

${ }^{35}$ Ladenburger, supra n. 25, para 7.

${ }^{36}$ CONV 354/02, supra n. 33, p. 8.

${ }^{37}$ Ibid., p. 4.

${ }^{38}$ Ibid., p. 8. Ladenburger, supra n. 25, para 7 and 10.

${ }^{39}$ Prechal, supra n. 17 , p. 179.

${ }^{40}$ The question as to whether this Protocol has any legal implications is much contested. The ECJ interpreted the legal implications of Art. 1(1) Protocol restrictively and argued that it 'does not intend to exempt the Republic of Poland or the United Kingdom from the obligation to comply with the provisions of the Charter'. The ECJ did not give any interpretation of Art. 1(2) or the rest of 
This section showed that the inclusion of social rights in the Charter was a controversial matter which could only be realised through making a distinction between rights and - weaker and less judicially cognisable - principles.

\section{DISTINCTION BETWEEN FOUNDING PRINCIPLES, GENERAL PRINCIPLES OF EU LAW AND SOCIAL RIGHTS}

Before turning to the distinction between rights and principles, a brief overview should be given of the distinction between Charter principles and three other categories of 'principles' in EU law. What distinguishes the three categories of principles discussed here from the principles in the sense of Article 52(5) of the Charter is the former's fundamental nature, while Article 52(5) principles have a weaker legal status (see next sections). ${ }^{41}$ First of all, there are the 'founding principles' of the EU. These can primarily be found in Title I TEU and include, for example, the principle of sincere cooperation (Article 4(3) TEU) and the principle of supremacy of EU law. ${ }^{42}$ The second subset includes the 'general principles of EU law'. Within this group, a distinction can be made between 'ordinary' general principles of EU law, such as the principle of proportionality, and general principles which relate to fundamental rights, such as the prohibition of torture or non-discrimination in respect of age. ${ }^{43}$ General principles of EU law have 'constitutional status', as the Court of Justice held in Audiolux. ${ }^{44}$ Given their constitutional status, general principles have a much stronger effect than

the Protocol, since the rights invoked in the proceedings did not deal with Title IV of the Charter. ECJ 21 December 2011, Joined Cases C-411/10 and C-493/10, N.S and M.E., para 116-122. See also A.G. Kokott, Opinion 15 December 2011, Case C-489/10, Bonda, para 21-23. S. Peers, 'The "Opt-out" that Fell to Earth: The British and Polish Protocol Concerning the EU Charter of Fundamental Rights', $14 \operatorname{HRLR}$ (2012) p. 1. C. Barnard, 'EU “social” policy: from employment law to labour market reform', in P. Craig and G. De Búrca (eds.), The evolution of EU law (Oxford University Press 2011) p. 641 at p. 659.

${ }^{41}$ The ECJ already held in Defrenne that 'this term [principle] is specifically used in order to indicate the fundamental nature of certain provisions'. Defrenne, supra n. 21, para 26. The changed use of principles in Art. 52(5) is thus 'somewhat paradoxical', as Prechal has noted, because the protection of fundamental rights in the EU legal order actually began by way of reference to general principles of law. Prechal, supra n. 16, p. 178 and 184. See text between n. 96 and 99 infra.

${ }^{42}$ A. Von Bogdandy, 'Founding Principles of EU Law: A theoretical and doctrinal sketch', 16 ELJ $2(2010)$ p. 95.

${ }^{43}$ ECJ 17 February 2009, Case C-465/07, Elgafaji, para 28. ECJ 19 January 2010, Case C-555/ 07, Kücükdeveci, para 21. S. Peers and S. Prechal, 'Article 52', in S. Peers et al. (eds.), The EU Charter of Fundamental Rights - A Commentary (Hart 2014), para 52.163.

${ }^{44}$ The ECJ did not accept that equality of shareholders was a general principle because it does not entail 'the general, comprehensive character which is otherwise naturally inherent in general principle of law'. ECJ 15 October 2009, Case C-101/08, Audiolux SA eav Groupe Bruxelles Lambert $S A(G B L)$, para 42 and 63. A.G. Trstenjak noted that general principles imply 'fundamental 
Charter principles. They have horizontal effect in as much as they can directly be relied upon by applicants even in disputes between private parties, as was confirmed in Mangold and Kücükdeveci. ${ }^{45}$ It is difficult to imagine that principles in the sense of Article 52(5) of the Charter, that cannot be directly relied upon, are classified as general principles. ${ }^{46}$ Thirdly, there are what the Court has referred to as 'particularly important principles of EU social law'. The Court of Justice introduced this concept in BECTU and qualified the entitlement of every worker to paid annual leave as such. ${ }^{47}$ In order to underline the important nature of these principles, the Court has referred to their unconditional character and held that 'there can be no derogations' from such principles. ${ }^{48}$

Arguably there is also a close relationship between social rights and principles in the sense of Article 52(5), as the previous section illustrated by looking at the inclusion of social rights in the Charter. Indeed, several social rights have the character of such Charter principles. Nonetheless, principles should not be equated with social rights. Two of the three examples of principles given in the Explanations (Articles 25 and 26) are actually provisions which are not in Chapter IV on solidarity, which is generally seen as the social rights section of the Charter. ${ }^{49}$ In addition, many Charter provisions in the social sphere are clearly individually enforceable rights as the Court determined in a few instances as well. ${ }^{50}$ This includes the landmark cases of Viking and Laval on the right to take collective action, which is laid down in Article 28 of the Charter. ${ }^{51}$ Thus, given these considerations, the Charter principles should not be equated with social rights.

principles' because of their hierarchical status as primary law; A.G.Trstenjak in Audiolux, para 66, 70 and 74 .

${ }^{45}$ The ECJ ruled that the general principle of non-discrimination on grounds of age as given expression by Directive 2000/78, must be interpreted as precluding national legislation; ECJ 19 January 2010, Case C-555/07, Kücükdeveci, para 43.

${ }^{46}$ Note that Art. 6(3) TEU stipulates that general principles of EU law are still a separate source of fundamental rights in addition to the rights, freedoms and principles in the Charter. This means that the Charter principles exist alongside - and must thus be distinguished from - the general principles of EU law encompassing fundamental rights. See also N. Lazzerini, '(Some of) the fundamental rights granted by the Charter may be a course of obligations for private parties: AMS', 51 CML Rev. (2014) p. 907 at p. 932. See also A.G. Kokott, Opinion 12 March 2015, Case C-83/14, CHEZ Razpredelenie Bulgaria ED, para 144.

${ }^{47}$ ECJ 26 June 2001, Case C-173/99, BECTU, para 40.

${ }^{48}$ Ibid., para 43. Text to n. 126 infra.

${ }^{49}$ Art. 25 (the rights of the elderly) and 26 (integration of persons with disabilities).

${ }^{50} \mathrm{~K}$. Lenaerts, 'Exploring the limits of the EU Charter of fundamental rights', 8 EuConst (2012) p. 375 at p. 399. R. O'Gorman, 'The ECHR, the EU and the weakness of social rights protection at the European level', 12 GLJ (2011) p. 1833 at p. 1835-1836. S. Fredman, 'Transformation or dilution: fundamental rights in the EU social space', 12 ELJ (2006) p. 41 at p. 42.

${ }^{51}$ ECJ 11 December 2007, Case C-438/05, Viking, para 44. ECJ 18 December 2007, Case C-341/05, Laval un Partneri, para 91. For subsequent cases on Article 28, see ECJ 
In conclusion, this short analysis shows that the notion of 'principles' in Article 52(5) should be clearly distinguished from general principles of EU law and 'particularly important principles of EU social law' as well as social rights.

\section{DisTINCTION BETWEEN RIGHTS AND PRINCIPLES IN THE CHARTER}

The precise difference between rights and principles is not obvious. No clear distinction is, for example, made in the text of the Charter itself, to the extent that principles are not contained in specific provisions or in a separate chapter. Most, but certainly not all, principles are included in Chapter IV on solidarity. This chapter at the same time includes rights, while there are also principles in other chapters. ${ }^{52}$ The language used in the Charter is not always indicative either. Only three provisions actually include the word 'principle', but it is evident that the Charter contains more principles. ${ }^{53}$ The other way around, the title of Article 49, for example, refers to 'principles of legality and proportionality of criminal offences and penalties' even though these are not principles in the sense of Article 52(5) Charter. ${ }^{54}$

The Explanations to the Charter provide some clarity by mentioning the following: 'For illustration, examples for principles, recognised in the Charter include e.g. Articles 25, 26 and 37. ${ }^{55}$ The Explanations also explicitly mention that several provisions lay down principles, including Articles 26, 34(1) and 35-38. The Explanations are, however, not consistent either, even though the Praesidium of the Second Convention tried to 'cleanse' the text of the Explanations drafted during the First Convention by making sure that the references to principles related to the distinction made in Article 52(5). ${ }^{56}$ The Explanations, for example, refer to 'the principles of Article 3 of the Charter' in relation to the 'right' to integrity of the person. ${ }^{57}$ In relation to the right to education laid down in Article 14, the Explanations mention 'the principle of free compulsory education. ${ }^{58}$ The Explanations also complicate the making of a

15 July 2010, Case C-271/08, Commission v Germany. ECJ 8 September 2011, Joined Cases C-297/10 and C-298/10, Hennings and Mai.

${ }^{52}$ Text to n. 49-50 supra. M. Gijzen, 'The Charter: A milestone for social protection in Europe', $8 M J(2001)$ p. 33 at p. 38. Kenner, supra n. 9, p. 17.

${ }^{53}$ Art. 23 (principle of equality), 37 (sustainable development) and 47 (legality and proportionality of criminal offences and penalties).

${ }^{54}$ Ladenburger, supra n. 33, p. 32. Prechal, supra n. 16, p. 182.

${ }^{55}$ O.J. 2007, C 303/35.

${ }^{56}$ CHARTE 4473/00, 'Text of the explanations relating to the complete text of the Charter as set out in CHARTE 4487/00 CONVENT 50', 11 October 2000.

${ }^{57}$ Ibid., p. 2.

${ }^{58}$ Ibid., p. 6. 
distinction between rights and principles by stipulating that in some cases, an Article of the Charter may contain both elements of a right and of a principle, e.g. Articles 23, 33 and 34. ${ }^{59}$

The absence of a clear distinction in the Charter is primarily the result of the inability of the two Conventions mentioned earlier to arrive at a consensus on a list distinguishing between rights and principles. The UK government, for example, wanted the Explanations to label more provisions of the Charter as principles than other member states. ${ }^{60}$ Given the disagreement, it was eventually decided to leave it to the Court of Justice to clarify the nature of the Charter's provisions on a caseby-case basis. ${ }^{61}$ Several scholars have rightly pointed out that a labelling of provisions is undesirable or counterproductive. ${ }^{62}$ The choice to leave it to judges in future cases, firstly, reflects that a categorisation of provisions is difficult to be made in the abstract and a priori. ${ }^{63}$ Making such a distinction is not a black-andwhite issue either, but clearly depends upon the context. ${ }^{64}$ This is well illustrated by the example given by Prechal about Article 15 on the freedom to choose an occupation and the right to engage in work. She argued that this provision cannot be invoked as a basis for action for damages in the case of unemployment, but it can be relied upon when the exercise of an occupation is made almost impossible or when access to certain professions is unreasonably limited. ${ }^{65}$ Secondly, the choice to leave it to the judiciary acknowledges that a distinction is not necessarily fixed in time and could change as a result of societal, legal and political developments. ${ }^{66}$

Scholars and politicians have formulated several criteria to distinguish between rights and principles, which echo the famous direct effect criteria of being 'unconditional and sufficiently clear and precise'. ${ }^{67}$ These criteria take the wording

${ }^{59}$ O.J. 2007, C 303/35.

${ }^{60}$ Art. 21, 23, 25, 28, 30, 31, 32, 33 and 34(3) should refer to 'principles' or Art. 52(5). Contribution of the Rt Hon Baroness Scotland of Asthal QC, Working Group II, WD 28, 12 June 2003.

${ }^{61}$ CONV 354/02, supra n. 33, p. 8. Lenaerts, supra n. 50, p. 400.

${ }^{62}$ Koukoulis-Spiliotopoulos, supra n. 23, p. 315.

${ }^{63}$ The Final Report of the Working Group II, nonetheless, talked about the 'exact attribution of Articles to the two categories'; CONV 354/02, supra n. 33, p. 8. Ladenburger, supra n. 33, p. 31. Burgorgue-Larsen, supra n. 1, p. 687. Peers and Prechal, supra n. 43, para 52.183.

${ }^{64}$ Prechal, supra n. 16, p. 182-183. M. De Mol et al., 'Inroepbaarheid in rechte van het Handvest van de Grondrechten van de Europese Unie: Toepassingsgebied en het onderscheid tussen "rechten" en "beginselen', $60 S E W(2012)$ p. 222 at p. 232.

${ }^{65}$ Prechal, supra n. 16, p. 182.

${ }^{66}$ K. Lenaerts, 'La solidarité ou le chapitre IV de la charte des droits fondamentaux de l'Union Européenne', 82 Revue trimestrielle des droits de l'homme (2010) para 43.

${ }^{67}$ Ladenburger, supra n. 25, para 98. ACA report, supra n. 32, para E10. T. Von Danwitz, 'Questionnaire', <aca-europe.eu/seminars/DenHaag2011/Report_ECJ.pdf>, visited 28 April 2014, para E3. 
of the text of the provisions in the Charter as the starting point, while the Explanations are subsequently used as a way to discern the object and purpose of the provision. ${ }^{68}$ The rest of this section discusses three yardsticks as well as their (practical) limitations. ${ }^{69}$ This overview aims to illustrate that the criteria are not decisive on their own and that there are limitations to their practical application in concrete cases.

The first and most cited criterion boils down to the question as to whether the provision actually aims to protect the rights of individuals. Former EU Commissioner Antonio Vitorino, who was the European Commission representative to the First Convention drafting the Charter, argued rather succinctly that there is a right "where the holder is clearly designated and that there is a principle where the EU is referred to as having to respect or recognize a specific value such as a healthy environment or protection of consumers. ${ }^{70}$ Thus, it is more likely that a provision is a right when it explicitly endows an individual with a subjective entitlement or claim (referring to rights) or when it specifically stipulates clear-cut obligations towards an individual, such as Article 2(2) of the Charter. ${ }^{71}$ For example, the use of the terms 'shall' in Article 33(1) and 'right' in Article 33(2) seem to indicate that these provisions are rights instead of principles. ${ }^{72}$ When a provision only outlines certain desirable objectives or obligations on the part of EU institutions and member states, such as the second part of Article 35, it is more likely that it is a principle. The second part of Article 35 provides: 'A high level of human health protection shall be ensured in the definition and implementation of all the Union's policies and activities.' Other phrases which primarily reflect a principled nature use the following terminology: 'The Union recognises and respects...' (Articles 25-26, 34(1), 34(3) and 36), '...must be integrated into the policies of the Union' (Article 37 on environmental protection), 'Union policies shall ensure...' (Article 38 on consumer protection). Because these provisions are worded as objective norms which are exclusively addressed to the state and avoid any reference to 'right' or 'individual', they are most likely principles. ${ }^{73}$ There are, however, several grey areas. Articles 25 and

\footnotetext{
${ }^{68}$ Von Danwitz, supra n. 67, para E3. Peers and Prechal, supra n. 43, para 52.170.

${ }^{69}$ Another criterion deals with the origin of a Charter provision. It has been argued that the provisions which correspond to the ECHR should be qualified as rights, even when they are broadly formulated. The Explanations to Art. 52(3) outline Charter provisions with a similar meaning and the scope as in the ECHR. O.J. 2007, C 303/32, 17-18. Ladenburger gave the examples of Art. 9, 48 and 49 , which are formulated in an objective way, but qualify as rights because they correspond to the ECHR. Ladenburger, supra n. 25, para 98.

${ }^{70}$ Vitorino as quoted in P. Craig, The Lisbon Treaty. Law, politics, and treaty reform (Oxford University Press 2010) p. 217.

${ }^{71}$ 'No one shall be condemned to the death penalty, or executed'.

${ }^{72}$ Interventions of Schoo, Piris and Petit on 23 July 2002, Working Group II, WD 13, 5 September 2002, p. 22.

${ }^{73}$ Ladenburger, supra n. 33, p. 32.
} 
26, for instance, are mentioned as examples of principles in the Explanations and include the above-mentioned sentence of 'The Union recognises and respects', yet at the same time contain the word 'rights'. The other way around, a Charter provision might have connotations of a right (in the sense of a droit subjectif) even though it is broadly formulated. One example is Article 22 of the Charter: 'The Union shall respect cultural, religious and linguistic diversity'. This Article is closely related to Article 27 of the International Covenant on Civil and Political Rights which has been interpreted by the UN Human Rights Committee as having direct effect and being justiciable in the sense of giving individuals the possibility to invoke the provision before the Committee. ${ }^{74}$

A second - closely related - yardstick is the extent to which the protection of fundamental rights depends upon further concretisation in laws. ${ }^{75}$ Rights generally do not depend upon legislative implementation and concretisation, while principles do. ${ }^{76}$ This can be illustrated by Article 37, which stipulates that '[a] high level of environmental protection and the improvement of the quality of the environment must be integrated into the policies of the Union and ensured in accordance with the principle of sustainable development.' Clearly, this Article does not immediately offer any entitlements, but merely lays down a broad obligation of effort requiring further implementation. Nonetheless, rights may be formulated in abstract or broad terms and may need further (legislative) concretisation and sometimes also positive action. The latter was also noted by Advocate General Trstenjak in Dominguez, who argued that rights are always worded to some extent in 'a legally abstract fashion' and 'are often designed to be fleshed out'. ${ }^{77}$

A third criterion identified in the literature relates to the margin of discretion a Charter provision leaves for the duty bearers, in particular the authorities of the EU institutions and member states. These duty bearers are said to have a larger margin of discretion when it comes to principles. ${ }^{78}$ This margin of discretion can be derived from references to conditions provided by Union law and/or national laws and practices. ${ }^{79}$ Article 30, for example, stipulates: 'Every worker has the right to protection against unjustified dismissal, in accordance with Union law and national laws and practices.' The problem, however, with this criterion is that this conditional language is also used in relation to several rights in Chapter II on freedoms, such as the right to marry and the right to found a family (Article 9) and

\footnotetext{
${ }^{74}$ Krommendijk, supra n. 15 , p. 348.

${ }^{75}$ De Mol et al., supra n. 64, p. 232.

${ }^{76}$ Ladenburger, supra n. 33, p. 32-33.

${ }^{77}$ A.G. Trstenjak, Opinion 8 September 2011, Case C-282/10, Dominguez, para 78.

${ }^{78}$ De Mol et al., supra n. 64, p. 232.

${ }^{79}$ Such references are made in the following Charter provisions: 9, 10(2), 14(3), 16, 27, 28, 30, $34(1),(2)$ and (3), 35 and 36.
} 
the freedom to found educational establishments (Article 14(3)). In addition, the Court of Justice has not shied away from attaching direct effect to provisions of primary and secondary EU law that include such references to limitations and conditions. In Baumbast, for instance, the Court concluded that Article 21 TFEU constitutes a directly effective right, despite references in that Article to the limitations and conditions that could be laid down in EU secondary law. ${ }^{80}$ Likewise, the Court determined in Viking and Laval that 'the right to take collective action, including the right to strike, must ... be recognised as a fundamental right which forms an integral part of the general principles of Community law'. It did do so despite the fact that the corresponding provision in the Charter, Article 28, which was used as a reaffirmation of this right, refers to 'Union law and national laws and practices' as well. ${ }^{81}$

In sum, the text of the Charter and the Explanations do not make an unambiguous distinction between rights and principles. Rather, the idea was to leave it to the Court of Justice to determine a provision's status on a case-by-case basis. Scholars and politicians have, nonetheless, developed several criteria which could help in making this distinction and structuring the Court's analysis, even though they do not, as such, provide any definite certainty. Section 6, which discusses the recent case law of the Court of Justice, examines whether these criteria have also been used by the Court. Before that, the question will be addressed of why the distinction between rights and principles is relevant.

\section{IMPLICATIONS OF THE DISTINCTION FOR JUDICIAL REVIEW}

Article 51(1), which was already included in the Charter by the First Convention before Article 52(5) was inserted by the Second Convention, stipulates that 'they [institutions and bodies of the Union and Member States] shall therefore respect the rights, observe the principles and promote the application thereof. At first glance, it seems that the obligation to 'observe' the principles is weaker than the obligation to 'respect' the rights. ${ }^{82}$ Nevertheless, this explanation is not a very convincing one. Several scholars have argued that the two verbs are synonyms and difficult to distinguish. ${ }^{83}$ The ordinary meaning of 'observe' is 'to obey a law, rule, or custom', 'to do what you are supposed to do according to a law or agreement $[=$ obey $]$ ' or to 'fulfil or comply with (a social, legal, ethical, or

\footnotetext{
${ }^{80}$ ECJ 17 September 2002, Case C-413/99, Baumbast, para 86.

${ }^{81}$ ECJ 11 December 2007, Case C-438/05, Viking, para 44. ECJ 18 December 2007, Case C-341/05, Laval un Partneri, para 91.

${ }^{82}$ A.W. Heringa and L. Verhey, 'The EU Charter: text and structure', 8 MJ 1 (2001) p. 11 at p. 14 .

${ }^{83}$ Koukoulis-Spiliotopoulos, supra n. 23, p. 297. J. Tooze, 'Social security and social assistance', in Hervey and Kenner, supra n. 9, p. 161 at p. 163
} 
religious obligation). ${ }^{84}$ Observing principles thus does not seem fundamentally different from respecting rights. ${ }^{85}$ Article 51 thus does not shed much light on the legal implications of the distinction.

The legal implications of the difference between rights and principles are spelled out more clearly in Article 52(5), which implies that judicial review should be more limited in respect of principles. Article 52(5) stipulates: 'The provisions of this Charter which contain principles may be implemented by legislative and executive acts taken by institutions, bodies, offices and agencies of the Union, and by acts of Member States when they are implementing Union law, in the exercise of their respective powers. They shall be judicially cognisable only in the interpretation of such acts and in the ruling on their legality.' This Article is, however, not very clear and can be interpreted in different ways. Several authors have differentiated between two possible interpretations. ${ }^{86}$ The first interpretation is based on a narrow textual interpretation of the wording of Article 52(5) and holds that judicial review of principles is limited to acts which give explicit expression to a principle. This is based on the last sentence of Article 52(5), which mentions that principles 'shall be judicially cognisable only in the interpretation of such acts and in the ruling on their legality' (emphasis added). 'Such acts' refers to the acts mentioned in the previous sentence: 'Legislative and executive acts taken by institutions, bodies, offices and agencies of the Union, and by acts of Member States when they are implementing Union law'. The Explanations further clarify that: 'Principles may be implemented through legislative or executive acts (adopted by the Union in accordance with its powers, and by the Member States only when they implement Union law); accordingly, they become significant for the courts only when such acts are interpreted or reviewed.' Judicial review seems thus limited to acts that explicitly and specifically aim to implement a Charter principle. The Explanations make clear that the limited judicial review to acts implementing principles is consistent with the case law of the Court of Justice as it stood when the Charter was drafted. ${ }^{87}$

The interpretation that principles can only be reviewed when there is an implementing measure is problematic, however, for several reasons. First of all, the Court has not limited its review to mere implementing acts of the principles mentioned in the Explanations. ${ }^{88}$ For example, the precautionary principle has

\footnotetext{
${ }^{84}$ These quotes are from the online dictionaries of Cambridge, Longman and Oxford.

${ }^{85}$ This was also noted by A.G Cruz-Villalón, supra n. 29, para 46.

${ }^{86}$ EU Network, supra n. 26, p. 407. De Mol et al, supra n. 64.

${ }^{87}$ In particular, reference is made here to case law on the 'precautionary principle', as laid down in Art. 191(2) TFEU and on Art. 33 TFEU related to the principles of agricultural law, including the principle of market stabilisation and of reasonable expectations. See respectively, CFI 11 September 2002, Case T-13/99, Pfizer v Council; ECJ 11 March 1987, Case C-265/85, Van den Berg.

${ }^{88}$ De Mol et al., supra n. 64, p. 234. Craig, supra n. 70, p. 220-221.
} 
been given a more autonomous reading and has been directly used as a standard of review in the recent case law of the Court of Justice and the General Court, although there was no reference to the principle in the (implementing) measure in question. ${ }^{89}$ Principles thus have a function beyond the one envisaged in the Explanations. The Court of First Instance, for instance, held in Artegodan that even though 'the precautionary principle is mentioned in the Treaty only in connection with environmental policy, it is broader in scope'. It implied that the principle can be an autonomous general principle of EU law which can be used as a standard of review in other areas such as public health and safety. ${ }^{90}$

Secondly, the narrow and literal interpretation has also been questioned from the perspective of the effet utile of EU law. A restrictive interpretation would prevent judicial review of clear violations of principles when the EU or member states fail or refuse to take action or when there are no measures that specifically aim to implement a specific principle. ${ }^{91}$ Ladenburger referred to such a reading as having 'absurd results' and he noted that this would also go against the intention of the drafters during the First Convention. ${ }^{92}$ He suggested that 'such acts' merely refers to the categories of acts, i.e. either legislative or executive acts, which can be judicially reviewed. Ladenburger referred to the Abdulla case for support. In this case, the Court held that the provisions in the 2004 asylum Qualification Directive, which were not specifically adopted with a view to implement certain Charter provisions, must 'be interpreted in a manner which respects the fundamental rights and the principles recognised in particular by the Charter' (emphasis added). ${ }^{93}$ Prechal also noted that the strict interpretation would be a 'serious drawback' in comparison with the earlier protection of fundamental rights by the Court of Justice where no such distinction was made. Pointing to ERT, she noted that all EU acts and national acts and measures falling within the scope of Community law can in principle be, and have in

\footnotetext{
${ }^{89}$ Prechal, supra n. 16, p. 183. The CFI held: 'It is not disputed by the parties that the [precautionary] principle also applies where the Community institutions take, in the framework of the common agricultural policy, measures to protect human health'. Pfizer, supra n. 87, para 114 and 125. Hilson, for example, pointed to ECJ 9 September 2003, Case C-236/01, Monsanto; ECJ 16 April 1991, Case C-290/90, Commission v Belgium; ECJ 29 April 1999, Case C-293/97, Standley. C. Hilson, 'Rights and principles in EU law: a distinction without foundation', $15 \mathrm{MJ}$ (2008) p. 192 at p. 199-202.

${ }^{90}$ CFI 26 November 2002, Case T-74/00, Artegodan, para 182 and 184. Hilson, supra n. 89, p. 199.

${ }^{91}$ Lenaerts, supra n. 50, p. 400. Burgorgue-Larsen, supra n. 1, p. 687-688. Peers and Prechal, supra n. 43, para 52.182.

${ }^{92}$ Ladenburger, supra n. 33, p. 33.

${ }^{93}$ ECJ 2 March 2010, Joined Cases C-175/08, C-176/08, C-178/08 and C-179/08, Abdulla and others, para 51 and 54.
} 
practice been, tested against fundamental rights irrespective of whether they intend to implement fundamental rights. ${ }^{94}$ In fact, the Court has held that 'respect of fundamental rights is a condition of the legality of Community acts'. ${ }^{95}$

In light of these problems, the majority of commentators favour a second interpretation of Article 52(5), which limits judicial review on the basis of principles to the way in which the review is conducted by courts. ${ }^{96}$ Review is limited in the sense that principles cannot give rise to 'direct claims for positive action by the Union's institutions or Member States authorities' or create standing before EU or national courts. ${ }^{97}$ The Final Report of the Working Group II of the Second Convention noted in this context that 'principles are different from subjective rights'. ${ }^{98}$ In other words, principles cannot act as a 'sword' or 'épée' (as a source of a new right). ${ }^{99}$

Nonetheless, principles can have a judicial function beyond this traditional narrow understanding of direct effect, since they can act as a shield or bouclier and offer protection against conflicting Community or national norms. Principles are limited to the extent that they cannot create locus standi for the individual, but when a litigant has standing on the basis of another ground than the principle, a judge can strike down a legislative or executive act on the basis of a principle in the Charter. ${ }^{100}$ Principles can thus be used as standards for legality review or tools of interpretation. This twofold function corresponds to the earlier discussed French tradition of 'limited justiciability' or justiciabilité mediate where principles can have an 'exclusionary effect' or invocabilité d'exclusion and exclude the application of a conflicting national or Community norm. ${ }^{101}$ This broader understanding of the possibilities for judicial review of principles also corresponds with more

${ }^{94}$ ECJ 18 June 1991, Case C-260/89 ERT, para 42. Prechal, supran. 16, 179. Peers and Prechal, supra $\mathrm{n}$. 43, para 52.182.

${ }^{95}$ ECJ 17 February 1998, Case C-249/96, Grant, para 45. ECJ 9 September 2003, Case C-25/02, Rinke, para 26.

${ }^{96}$ EU Network, supra n. 26, p. 407. H.M. Sagmeister, Die Grundsatznormen in der Europäischen Grundrechtecharta (Duncker \& Humblot 2010) p. 181 and 265-267. Braibant, supra n. 16, p. 46. Koukoulis-Spiliotopoulis, supra n. 23, p. 292. Peers and Prechal, supra n. 43, para 52.181-182.

${ }^{97}$ O.J. 2007, C 303/32, 19. Ladenburger, supra n. 25, para 86.

${ }^{98}$ CONV 354/02, supra n. 33, p. 8.

${ }^{99}$ The limited possibilities for judicial review reflects the idea that a provision of EU law can only produce an independent effect (within national legal systems) after it has satisfied the criteria of direct effect. This is what Dougan referred to as the 'trigger model'. M. Dougan, 'When worlds collide! Competing visions of the relationship between direct effect and supremacy', 44 CML Rev. (2007) p. 931 at p. $934-937$.

${ }^{100}$ Ladenburger, supra n. 33, p. 33. EU Network, supra n. 27, p. 406.

${ }^{101}$ See text between n. 28 and 31 supra. Lenaerts, supra n. 50, p. 400-401. Von Danwitz, supran. 67, para E4. B. De Witte, 'Direct effect, primacy, and the nature of the legal order', in P. Craig and G. De Búrca (eds.), The Evolution of EU Law (Oxford University Press 2011) p. 323 at p. 331. 
expansive readings of the notion of direct effect. ${ }^{102}$ These readings posit that a provision of EU law can have independent 'exclusionary effects' independently of the principle of direct effect when there is a provision of national law that is incompatible with this provision of EU law. ${ }^{103}$ They treat the primacy or supremacy of EU law as the dominant concept governing the relationship between EU law and national law. ${ }^{104}$

The broader interpretation is also in line with the case law, cited in the Explanations, in which the Court has ruled on the legality of acts and has set aside legislation that was not in conformity with the principle. In Pfizer, the Court of First Instance, for example, tested the conformity of a Regulation with the precautionary principle. ${ }^{105}$ The Court has not been precluded from reviewing the legality of national acts in the light of imprecise and insufficiently clear EU norms in other cases as well. ${ }^{106}$ In Kraaijeveld, for example, the Court dealt with rather broadly formulated provisions in the Environmental Impact Assessment Directive. It held that the fact that member states had certain discretion did 'not preclude judicial review of the question whether the national authorities exceeded their discretion'. ${ }^{107}$ The Commentary of the EU Network of Experts also noted that the broader second interpretation would be more faithful to the intention of

${ }^{102}$ De Witte noted that direct effect has originally been construed as the creation of rights for individuals, but has over time been replaced by the notion of invocability, whereby a norm can act as a standard for review of the legality if it is 'sufficiently operational in itself to be applied by a court'; De Witte, supra n. 101, p. 330-331. Likewise, Prechal highlights the application of a provision of EU law 'either as a norm which governs the case or as a standard for legal review' as the defining feature of the broader concept of direct effect; S. Prechal, 'Direct effect, indirect effect, supremacy and the evolving Constitution of the European Union', in C. Barnard (ed.), The fundamentals of EU law revisited (Oxford University Press 2007) p. 35 at p. 37-38. For a further discussion of the different understandings of direct effect, see E. Muir, 'Of ages in - and edges of - EU law', $48 C M L$ Rev. (2011) p. 39.

${ }^{103}$ Concrete expressions of these broader readings are the doctrines of indirect effect, the duty of consistent or harmonious interpretation for national courts, and incidental horizontal effect. The ECJ, for example, explicitly determined that judicial review is not precluded even if the provisions do not have direct effect; ECJ 9 October 2001, Case C-377/98, Kingdom of the Netherlands v European Parliament/ Council, para 54. Likewise, the ECJ held in Pupino that the exclusion of direct effect of (framework) decisions in the former third pillar did not preclude consistent interpretation; ECJ 16 June 2005, Case C-105/03, Pupino. De Witte, supra n. 101, p. 337. For a good overview, see P. Craig and G. De Búrca (eds.), EU Law. Text, cases, and materials (Oxford University Press 2011) p. $200-211$.

${ }^{104}$ Dougan labeled this as the 'primacy model' as opposed to the 'trigger model'. Dougan, supra n. 99, p. 932-933.

${ }^{105}$ De Mol et al., supra n. 64, p. 234.

${ }^{106}$ De Witte referred in this context to ECJ 24 April 2008, Cases C-55/07 and C-56/07, Othmar Michaeler and others; De Witte, supra n. 101, p. 332. See also n. 103 supra.

${ }^{107}$ This case dealt with Art. 2(1) of Directive 85/337. ECJ 24 October 1996, Case C-72/95, Kraaijeveld, para 59. 
the drafters of the First Convention. ${ }^{108}$ Likewise, the representative of the French government to the First Convention, Guy Braibant, argued that Article 52(5), read in conjunction with Article 53, would make it possible to strike down EU or national measures that conflict with principles. ${ }^{109}$ Even the UK representative during the First Convention, Lord Goldsmith, recognised 'that the Union should not violate this principle by a side wind in some other legislation within its competence'. ${ }^{110}$

In summary, it can be argued that the main difference between rights and principles is that the latter cannot create standing or give rise to direct claims for positive action before courts. Nonetheless, it is submitted that both rights and principles can be used as judicial standards for legality review of EU and national acts and measures, as well as standards or tools of interpretation. One limitation for Charter principles, however, is that the intensity of the review of acts and practices is generally more limited than rights. ${ }^{111}$

\section{Recent case law of the Court of Justice}

The previous sections showed that the distinction between rights and principles received much attention during the negotiations of the Charter and has been extensively discussed in literature as well. The question remains as to whether this distinction has also played an important role in the case law of the Court. In order to answer this question, this section discusses some recent cases decided by the ECJ which dealt with (Glatzel) or could have dealt with the distinction (Dominguez, Kamberaj, AMS and Pohotovost). The analysis will primarily focus on the criteria used to make a distinction and the implications of this (lack of) distinction for the review the Court has conducted (or not).

\section{Article 31(2): Dominguez and Heimann}

Until the Glatzel case, the Court did not expressly deal with the distinction between rights and principles in the Charter. One of the first opportunities it could have done so was Dominguez. Ms Dominguez claimed 22.5 days of paid leave from her employer for the 14-month period she had been absent from work after an accident. The case touched upon the interpretation of Article 31(2), on the

\footnotetext{
${ }^{108}$ EU Network, supra n. 26, 406. De Mol et al., supra n. 64, p. 234.

${ }^{109}$ Burgorgue-Larsen, supra n. 1, p. 684 and 687.

${ }^{110}$ Goldsmith, supra n. 17 , p. 1213.

${ }^{111}$ This also corresponds to the approach of the ECJ in relation to the precautionary principle where it held that the Community institutions have a broad discretion. Pfizer, supra n. 87, para 166-170. De Mol et al., supra n. 64, p. 235. Craig, supra n. 70, p. 220. Von Danwitz, supra n. 67, para E4. Peers and Prechal, supra n. 43, para 52.183.
} 
right to paid annual leave, and its horizontal direct effect. ${ }^{112}$ Strikingly, in its judgment the Court did not refer to the Charter at all, even though it had requested the parties during the proceedings before the Grand Chamber to focus on horizontal direct effect and Article 31(2) of the Charter in their pleadings. ${ }^{113}$ It merely held that the entitlement of every worker to paid annual leave is 'a particularly important principle of European Union social law from which there can be no derogations' and that '[Member States] are not entitled to make the very existence of that right subject to any preconditions whatsoever.. ${ }^{114}$ The Court then ruled that national provisions or practices, which make entitlement to paid annual leave conditional on a minimum period of ten days' or one month's actual work during the reference period, are contrary to the Directive. ${ }^{115}$

Two issues deserve special attention. Firstly, it is interesting to see how the Court dealt with the reference to discretion of member states, which relates to the third criterion for making a distinction between rights and principles. Article 7(1) of the EU Working Time Directive 2003/88/EC stipulates that 'Member States shall take the measures necessary to ensure that every worker is entitled to paid annual leave of at least four weeks in accordance with the conditions for entitlement to, and granting of, such leave laid down by national legislation andlor practice' (emphasis added). This conditional language was no reason for the Court to rule that Article 7(1) is merely an aspirational norm. The Court held that even though Member States have some freedom to apply the requirements of the relevant Directive (2003/88/EC) in practice, they cannot 'exclude the very existence of a right expressly granted to all workers. ${ }^{11}$

Secondly, the Court used several terms interchangeably, referring to the 'entitlement of every worker', 'the right to paid annual leave' as well as a 'principle of European Union social law'. Thus, the Court far from clarified the precise status of this right or principle. In addition, it remained unclear whether the 'principle of European Union social law' should be seen as the same as a 'principle' in the sense

\footnotetext{
${ }^{112}$ Art. 31(2) stipulates: 'Every worker has the right to limitation of maximum working hours, to daily and weekly rest periods and to an annual period of paid leave.'

${ }^{113}$ This contrasts with two earlier judgments in which the ECJ made a passing reference to Art. 31(2). ECJ 15 September 2011, Case C-155/10, Williams, para 18; ECJ 22 November 2011, Case C-214/10, KHS, para 37. Nonetheless, the ECJ failed to refer to Art. 31(2) in ECJ 14 October 2010, Case C-243/09, Fuß; ECJ 22 April 2010, Case C-486/08, Zentralbetriebsrat der Landeskrankenhäuser Tirols.

${ }^{114}$ Dominguez, supra n. 3, para 16 and 18 . In this context, the ECJ referred to BECTU, supra n. 47.

${ }^{115}$ Ibid., para 21.

${ }^{116}$ Ibid., para 18 and 19. This is in line with the earlier case law of the ECJ. In Jaeger, the ECJ held: 'the fact that the definition of the concept of working time refers to "national law and/or practice" does not mean that the Member States may unilaterally determine the scope of that concept.' ECJ 9 September 2003, Case C-151/02, Jaeger, para 59. See also: BECTU, supra n. 47, para 53.
} 
of Article 52(5) of the Charter or as a general principle of EU law. ${ }^{117}$ By leaving these matters undecided, the Court basically ignored the in-depth analysis of Advocate General Trstenjak in her Opinion concerning the legal status and the nature of the right to paid annual leave. ${ }^{118}$ The Advocate General considered that Article 31(2) constituted a 'social fundamental right'. She explicitly ruled out that Article 31(2) is a principle 'which do[es] not create any direct subjective rights'. Trstenjak primarily relied on the first criterion for making a distinction between rights and principles, as discussed above. She thereby based her reading on the wording of Article 31(2), which explicitly refers to a 'right' for every worker and hence includes, in her view, a 'guarantee' and 'an individual requirement'. She also noted a difference between Article 31(2) and other provisions in Chapter IV, which are worded like 'a guarantee of objective law in that the rights granted there are 'recognised' or 'respected". ${ }^{119}$ In this regard she noted that 'these differences in wording are evidence of a graduated intensity of protection according to the legal right concerned'. ${ }^{120}$ Finally, she based her determination on a 'systematic interpretation' of the structure of the Charter by relying on the 'proximity [...] substantive connection and structural similarities' of Article 31 to Articles 28 and 29, which are rights. ${ }^{121}$

In a subsequent case on paid annual leave, Heimann, the Court reflected on the nature of Article 31(2) of the Charter in a rather similar manner as in its previous judgment in Dominguez. The Court again held that Article 31(2) as a 'particularly important principle of European Union social law [...] may not be interpreted restrictively. ${ }^{122}$ Just as in Dominguez, the Court used the terminology of rights, principles of social law and entitlement interchangeably. In particular, it held in a rather mystifying way that 'the right to paid annual leave is, as a principle

\footnotetext{
${ }^{117}$ According to Peers and Prechal, the ECJ wanted to emphasise the fundamental character of entitlement with its reference to 'a particularly important principle'. They understood this as an implicit reference to the general principles of EU law; Peers and Prechal, supra n. 43, para 52.165. De Mol, however, noted that the ECJ did not determine that the right is a general principle of EU law; M. De Mol, 'Dominguez: A deafening silence', 8 EuConst (2012) p. 280 at p. 282.

${ }^{118}$ A.G. Trstenjak held that 'the Court is being invited to state how entitlement to paid annual leave should be categorised within the hierarchy of norms' in the EU legal system; Trstenjak, supra n. 77, para 3. See also L. Pech, 'Between judicial minimalism and avoidance: the Court of Justice's sidestepping of fundamental constitutional issues in Römer and Dominguez, 49 CML Rev. (2012) p. 1841 at p. $1852-1853$.

${ }^{119}$ It is interesting that Trstenjak used the term 'respect' for principles, whereas Article 51(1) links 'respect' to rights'. Ibid., para 76.

${ }^{120}$ Idem.

${ }^{121}$ Ibid., para 79.

${ }^{122}$ ECJ 8 November 2012, Joined Cases C-229/11 and C-230/11, Heimann, para 22 and 23. See also, among many other judgments, ECJ 19 September 2013, Case C-579/12 RX-II, European Commission v Strack, para 26.
} 
of European Union social law, expressly laid down in Article 31(2) of the Charter'. ${ }^{123}$ The silence of the Court on the nature of Article 31(2) notwithstanding, the Heimann case illustrates that the Article can be used as a standard of legality against which national legislation or practices can be reviewed. The Court examined the preliminary reference from a German court as to whether Article 31(2) of the Charter or Article 7(1) of Directive 2003/88 must be interpreted as precluding national legislation or practice, in this case a social plan agreed between an undertaking and its works council, under which the paid annual leave of a worker on short-time working is calculated according to the rule of pro rata temporis. The Court eventually answered the question in the negative.

As said, it is still unclear whether Article 31(2) is an individual right which can be directly invoked before courts. ${ }^{124}$ The Court of Justice has not expressed itself on this matter (yet). Nonetheless, it seems to follow from Dominguez and Heiman that it accepts that this 'principle of EU social law' can be classified as a right in the sense of Article 52(5) of the Charter. After all, in these cases the Court referred to the 'right' to paid annual leave five and nine times respectively and it also referred to a notion of 'entitlement', while both terms are commonly used to denote individual rights. ${ }^{125}$ Secondly, the Court highlighted the unconditional character of the 'right' and noted that this 'right' should not be interpreted restrictively. ${ }^{126}$

\section{Article 34(3): Kamberaj}

A second opportunity for the Court to rule on the distinction presented itself with the Kamberaj case, which concerned Article 34(3) of the EU Charter on the right to housing assistance. ${ }^{127}$ This article is seen by most commentators as a principle in the sense of Article 52(5). ${ }^{128}$ Contrary to Dominguez, this case did not

\footnotetext{
${ }^{123}$ Dominguez, supra n. 3, para 22. The ECJ used this phrase for the first time in Neidel. ECJ 3 May 2012, Case C-337/10, Neidel, para 40.

${ }^{124}$ The fact that the ECJ did use Art. 31(2) as a standard of legality does not tell us anything about the nature of Art. 31(2). This is because, at least in a wide reading of the competence of the Court under the Charter, both rights and principles can be used as standards of review, as shown above. Nonetheless, the ECJ did not examine whether Directive 2003/88/EC actually implements Art. 31(2). This would be relevant if the ECJ is of the view that Art. 31(2) is a principle in the sense of Art. 52(5) and when it favours a restrictive interpretation of Art. 52(5), limiting review to measures implementing principles.

${ }^{125}$ See text to n. 70-71 supra.

${ }^{126}$ See text to n. 48 supra. Dominguez, supra n. 3, para 18-20. Heimann, supra n. 122, para 23.

${ }^{127}$ Art. 34(3) provides: 'In order to combat social exclusion and poverty, the Union recognises and respects the right to social and housing assistance so as to ensure a decent existence for all those who lack sufficient resources, in accordance with the rules laid down by Community law and national laws and practices.'

${ }^{128}$ Kenner, supra n. 9, p. 23. De Mol et al., supra n. 64, p. 233. Gijzen, supra n. 52, p. 40. Tooze, supra n. 83, p. 163.
} 
concentrate on 'employment related social policy', but it dealt with a social issue, i.e. housing and related benefits. ${ }^{129} \mathrm{Mr}$ Kamberaj, an Albanian national who had resided and been employed in the Italian region of Bolzano since 1994, had claimed housing benefits for the year 2009, but these had been rejected on the ground that the budget for the grant of that benefit to third-country nationals had been exhausted.

Neither Advocate General Bot nor the Court used this opportunity to clarify the distinction and the legal character of Article 34 of the Charter. This, however, did not prevent the Court from relying on Article 34(3) as a standard of interpretation of Article 11(1)(d) of Directive 2003/109/EC concerning the status of third-country nationals who are long-term residents. ${ }^{130}$ This Article makes it possible to limit social assistance benefits for long-term residents to core benefits. Recital 13 to this Directive clarifies that core benefits include at least minimum income support as well as assistance in case of illness, pregnancy, parental assistance and long-term care. Taking Article 34 into account, the Court basically concluded that housing benefits also have to be regarded as such core benefits that cannot be limited. More specifically, reading Article 11(1)(d) in conjunction with Article 34 of the Charter, the Court ruled that Article 11(1)(d) can preclude a national or regional law which treats third-country nationals enjoying the status of long-term residents differently from nationals when it comes to housing benefits. Thus, the Court did not interpret the rather conditional language of Article 34 as excluding judicial review altogether, nor - as Goldsmith has argued - did it read the Article as meaning that the Charter should not interfere with national legislation in the field of social rights and principles. ${ }^{131}$ While the Court did not use Article 34(3) as the standard of review, but based its findings on the provision in the Directive instead, it did use the Article to interpret the relevant provision of the Directive in a Charter-friendly way. ${ }^{132}$ In doing so, the Court basically applied the second broader interpretation of Article 52(5), as discussed above, by using Article 34 to interpret a Directive that was not intended to implement Article 34.

A disappointing aspect of the judgment is the way in which the Court of Justice used Article 34(3). There is a significant lack of detail in the 'test' the Court performed. The Court referred to Article 34 of the Charter in a general way and failed to specify which of the different paragraphs of this Article it had in mind. This is noteworthy because there is a difference between the three paragraphs in

\footnotetext{
${ }^{129}$ For this distinction, see Barnard, supra n. 40, p. 660.

${ }^{130}$ J. Morijn, European Human Rights Cases 2012/162, para 10.

${ }^{131}$ Kamberaj, supra n. 4, para 81 and 92. Goldsmith, supra n. 17, p. 1213.

${ }^{132}$ This is what Robin-Olivier referred to as 'combined effects' of norms as a result of their association ('normative combination') with other EU law provisions irrespective of whether norms are capable of having direct effect; S. Robin-Olivier, 'The evolution of direct effect in the EU: stocktaking, problems, projections', 12 ICON (2014) p. 165 at p. 171-175.
} 
terms of content, specificity and level of protection. ${ }^{133}$ In addition, the Court did not refer to the Explanations to Article 34. ${ }^{134}$ This lack of precision runs counter to the ambitious expectations expressed by Advocate General Bot, who had argued that 'the present case offers the Court the opportunity to determine the scope of some of the conditions and restrictions and the way in which to reconcile them with the objectives referred to in Directive 2003/109 and with fundamental rights as guaranteed inter alia by Article 34 of the Charter.' ${ }^{135}$

To sum up, in Kamberaj the Court did not rule on the nature of Article 34(3) as either a right or a principle. The Kamberaj case illustrates that - as is most likely - a principle can indeed have an interpretive function, even in relation to acts that do not explicitly implement that principle. Such an interpretation in conformity with Article 34 was also proposed by Advocate General Cruz Villalón in the subsequent case of $\breve{C} a s t a .{ }^{136}$

\section{Article 27: AMS}

The third occasion during which the Court could have provided more certainty arose with the AMS case, which concerned Article 27 of the Charter on workers' rights to information and consultation within the undertaking. ${ }^{137}$ AMS, an association for the reintegration of unemployed persons, challenged and consequently suspended the appointment of Mr Laboubi as a trade union representative. AMS was of the opinion that this appointment was not required since it only employed 11 staff members, while the Directive 2002/14 and the French Labour Code only made the appointment of a representative obligatory for workplaces with more than 50 employees. In line with the French Labour Code, but contrary to the Directive, AMS excluded from its calculation the between 120 and 170 employees it had with a specific type of contracts ('accompaniedemployment'). The Grand Chamber of the Court concluded that the French provision in the Labour Code was incompatible with Article 3(1) of Directive 2002/14. The Court did not make a pronouncement on the conformity of the Code with Article 27 of the Charter. Instead, it repeated its settled case-law as to the prohibition of horizontal direct effect of directives, even when they are

${ }^{133}$ Morijn, supra n. 130, para 12.

${ }^{134}$ Ibid., para 11.

${ }^{135}$ A.G. Bot, Opinion 13 December 2011 in Kamberaj, supra n. 4, para 54.

${ }^{136}$ A.G. Cruz Villalón held that Art. 34(1) 'cannot be overlooked in interpreting the provision at issue', Art. 11(2) of Annex VIII to the Staff Regulations of Officials of the EU; A.G. Cruz Villalón, Opinion 27 June 2013, Case C-166/12, Radek Časta v Česká správa sociálního zabezpečení, para 63. The ECJ paid no attention to the Charter in its judgment.

${ }^{137}$ Art. 27 stipulates: 'Workers or their representatives must, at the appropriate levels, be guaranteed information and consultation in good time in the cases and under the conditions provided for by Union law and national laws and practices.' 
clear, sufficiently precise and unconditional. ${ }^{138}$ It also observed that an EU-conform interpretation of the French provision was impossible since this would result in a contra legem interpretation. ${ }^{139}$ In this light, it was left with answering the question as to 'whether the situation in the case in the main proceedings is similar to that in the case which gave rise to Kücükdeveci [...], so that Article 27 of the Charter, in and of itself or in conjunction with the provisions of Directive 2002/14, can be invoked in a dispute between individuals in order to preclude, as the case may be, the application of the national provision which is not in conformity with that directive. ${ }^{140}$

The Court did not pay attention to the question of whether Article 27 is a principle or a right. The Court thus did not fulfil the 'task' it had in the view of Advocate General Cruz-Villalón, who had reasoned that the case offered the possibility 'to ascertain the possible status as a 'principle' of Article 27 of the Charter'. ${ }^{141}$ The Court rather chose to frame the issue in terms of (horizontal) direct effect of a Charter provision. But even in relation to this question, the Court spent only few words on exactly how it can be determined whether a provision is sufficiently clear as to confer an individual right onto individuals. ${ }^{142}$ The ECJ first considered that the case was different from Kücükdeveci, in which it had considered that the general principle of non-discrimination on the ground of age was sufficiently clear for individuals to rely on it and thus to have horizontal direct effect. ${ }^{143}$ It then referred to the wording of Article 27 and Article 21(1) of the Charter (the first criterion discussed above) to explain the difference between the two provisions. It considered that Article 27 of the Charter is not 'a directly applicable rule of law', since it is generally formulated and not sufficient in itself to confer a right on individuals which they can invoke before a national court. ${ }^{144}$ In addition, the Court implicitly relied on the second yardstick discussed above by considering that 'for this Article [i.e. Article 27] to be fully effective, it must be given more specific expression in European Union or national law'. ${ }^{145}$ This 'concretisation argument' is remarkable in the light of the case law of the Court

${ }^{138}$ AMS, supra n. 5, para 36.

${ }^{139}$ Ibid., para 39-40.

${ }^{140}$ Ibid., para 41.

${ }^{141}$ Cruz-Villalón, supra n. 29, para 42. For a critical analysis, see E. Frantziou, 'Case C-176/12 Association de Médiation Sociale: Some reflection on the horizontal effect of the Charter and the reach of fundamental employment right in the European Union', 10 EuConst (2014), p. 332.

${ }^{142}$ According to Frantziou, the ECJ added a new hierarchy of rights-conferring and non-rightsconferring Charter provisions in addition to the rights-principle distinction. Frantziou, supran. 141, p. 344-346.

${ }^{143}$ The ECJ recognised that this principle is laid down in Art. 21(2) of the Charter as well; Kücükdeveci, supra n. 45, para 22.

${ }^{144} A M S$, supra n. 5, para 46-47.

${ }^{145}$ Ibid., para 45. 
discussed earlier, such as Baumbast, in which the Court considered that certain provisions of the Charter can have direct effect even though they refer to limitations and conditions. ${ }^{146}$ Be that as it may, the Court eventually concluded that Article 27 cannot be invoked in a (horizontal) dispute 'such as that in the main proceedings. ${ }^{147}$

Although the ECJ did not use the language of rights and principles, the argument could be made that the Court's reasoning in AMS basically implies that Article 27 constitutes a principle, while Article 21(1) can be regarded as a right. ${ }^{148}$ Such a conclusion would correspond well with the conclusion of Advocate General Cruz Villalón, who went to great lengths to answer the question as to whether Article 27 of the Charter is a principle or right. In fact, almost half of the Advocate General's Opinion was devoted to the issue of the distinction between rights and principles and the consequence of such categorisation. ${ }^{149}$ Given the objectives of this article, it is interesting to take a closer look at the Opinion and the criteria used.

Firstly, Advocate General Cruz Villalón based his conclusion that Article 27 of the Charter constitutes a principle on the provision's 'substantive content'. ${ }^{150} \mathrm{He}$ held that 'social rights' are social rights by virtue of their subject matter or content, i.e. because they deal with social policy, and 'principles' by virtue of their operation, i.e. because they cannot give rise to legally enforceable individual claims. ${ }^{151}$ Cruz Villalón also used a 'systemic argument' based on its inclusion in title IV on solidarity. ${ }^{152} \mathrm{He}$ noted that there is 'a strong presumption' that the provisions in this chapter entail principles. ${ }^{153}$ This is, however, a rather one-dimensional - and also factually incorrect - depiction of several of the provisions in Chapter IV, as was already discussed above. ${ }^{154}$ Most of the Articles

${ }^{146}$ See text to n. 80-81 supra.

${ }^{147}$ AMS, supra n. 5, para 48. It is still uncertain whether Art. 27 can never meet the criteria for direct effect. It cannot be ruled out that the ECJ would arrive at a different conclusion when the facts of the case are different. M. De Mol, European Human Rights Cases 2014/70, para 6. Frantziou, supra n. 141 , p. 339-340.

${ }^{148}$ Alternatively, Art. 27 might also be a 'right' which does not fulfill the conditions for direct effect. Lazzerini, supra n. 46, p. 932.

${ }^{149}$ Cruz-Villalón, supra n. 29, para 43-80.

${ }^{150}$ Ibid., para 53.

${ }^{151}$ Ibid., para 45.

${ }^{152}$ Ibid., para 53 and 55. The ECJ had earlier referred to the different character of the provisions in Title IV when it noted that Article 16 Charter 'differs from the wording of other fundamental freedoms laid down in Title II thereof, yet is similar to that of certain provisions of Title IV of the Charter'. The ECJ furthermore noted the 'broad range of interventions' which may limit Art. 16; ECJ 22 January 2013, C-283/11, Sky Österreich GmbH v Österreichischer Rundfunk, para 46.

${ }^{153}$ Cruz-Villalón, supra n. 29, para 55.

${ }^{154}$ See text to n. 49-51 supra. 
in this chapter (broadly speaking; Articles 28-33) are - contrary to what the Advocate General seems to imply - formulated fairly concretely. Articles 28-33 seem to be capable of conferring a right on individuals even when one adopts a purely textual interpretation. Article 29, for example, stipulates that 'everyone has the right to...', while Articles 30 and 31 (1) and (2) determine that 'every worker has the right to.... ${ }^{155}$ In arguing that Chapter IV on solidarity predominantly includes principles, Cruz Villalón implicitly reinforces the existing dichotomy between enforceable and justiciable civil and political rights, on the one hand, and so-called economic, social and cultural rights, on the other. ${ }^{156}$ It is questionable if this view can be reconciled with the aims of the drafters of the Charter, since they actually aimed to overcome this dichotomy by including both these rights in the same document. ${ }^{157}$

Secondly, Advocate General Cruz Villalón noted that the scope of Article 27 is 'extremely weak' and its content 'indeterminate' because it includes a reference to 'in accordance with Union law and national laws and practices'. ${ }^{158}$ In doing so, the Advocate General basically combined the first criterion with respect to the wording, as well as the third criterion dealing with the margin of discretion for duty bearers (see above). This reading of Article 27 can be criticised, however, because the wording of Article 27 is actually not so weak as it stipulates that something 'must be [...] guaranteed'. ${ }^{159}$ As was mentioned before, the fact that a provision refers to 'limitations and conditions' has not precluded judicial review. ${ }^{160}$

The Advocate General. also dealt with the question of the justiciability of principles in the sense of Article 52(5) and the question of which acts can be reviewed in the light of principles, a matter which was discussed above. He argued that if 'such acts' would only refer to implementing legislative acts, there would be a 'vicious circle'. This is because implementing acts could then only be reviewed in the light of a principle of which the substance is at the same time determined by the same act which implements and gives specific substantive and direct expression to the content of the principle. ${ }^{161}$ In line with most commentators, Advocate General Cruz Villalón thus favoured the broader second interpretation as

${ }^{155}$ See also Trstenjak, supra $\mathrm{n} .77$.

${ }^{156}$ Fredman warned that Art. 52(5) 'threatens to resuscitate the well-worn division between civil and political rights and socio-economic rights'. Fredman, supra n. 50, p. 43.

${ }^{157}$ See text to n. 12 supra.

${ }^{158}$ Cruz-Villalón, supra n. 29, para 54.

${ }^{159}$ Kenner held that Art. 27 entails a 'qualified guarantee' and hence 'blur[s] the rights/ principles distinction'; Kenner, supra n. 9, p. 19-20. Ladenburger also mentioned Art. 27 as one of the 'hardest cases of doubt'; Ladenburger, supra n. 33, p. 32.

${ }^{160}$ See text to n. 80-91 and 146 supra.

${ }^{161}$ Cruz-Villalón, supra n. 29, para 69. 
identified in Section 5 which enables the review of the legality of other acts going beyond the implementing act. ${ }^{162}$

In conclusion, it is clear that in $A M S$, the Court did not provide any clarity as to the status of Article 27 as a principle or a right in the sense of Article 52(5) of the Charter. Rather, it framed the question in terms of (horizontal) direct effect of a Charter provision and concluded for these purposes that Article 27 did not have direct effect, given the Article's wording and the necessity of further concretisation.

\section{Article 38: Pohotovost and Kušionová}

In another case, which was decided shortly after $A M S$, the Court again remained silent on the nature of a Charter provision, in this case Article 38 which provides that EU policies 'shall ensure a high level of consumer protection'. ${ }^{163}$ In this case, the Court was confronted with the request for a preliminary ruling as to whether a consumer protection association can intervene in support of a consumer in proceedings for enforcement of a final arbitration award against that consumer. The Court did not make a pronouncement on the nature of Article 38, even though Advocate General Wahl had explicitly determined that this provision is ' $a$ principle and not a right'. ${ }^{164}$ The Advocate General exclusively referred to the first criterion for the distinction as discussed above and noted that this article has nothing to say about a directly defined individual legal position. ${ }^{165}$ Interestingly, he did not mention that the Explanations to the specific article did refer to 'principles set out in this article' and only noted that the Explanations did not mention Article 38 as one of the three examples of a Article 52(5) principle. ${ }^{166}$

In terms of possibilities for judicial review, the Court of Justice explicitly accepted that the 'requirement' of Article 38 'applies to the implementation' of Directive 93/13 on unfair terms in consumer contracts. ${ }^{167}$ The Court accepted that Article 38 can be used as a tool to interpret the Directive. ${ }^{168}$ Interpreting the

${ }^{162}$ See text between n. 96 and 110 supra.

163 'Union policies shall ensure a high level of consumer protection'.

${ }^{164}$ A.G. Wahl referred to Opinion of A.G. Cruz Villalón in $A M S$ with respect to the distinction and the conditions under which principles can be invoked; A.G. Wahl, Opinion 12 December 2013 in Pohotovost, supra n. 6, para 66.

${ }^{165}$ Ibid.

${ }^{166}$ Ibid. O.J. 2007, C 303/02, p. 12 and 19.

${ }^{167}$ Pohotovost, supra n. 6, para 52.

${ }^{168}$ The ECJ did not explicitly state that Directive 93/13 implements Art. 38 Charter within the meaning of Art. 52(5) Charter. Note that Directive 93/13 only refers to Art. 100 EEC (now 115 TFEU) and not Art. 129a(1) EC (now 169 TFEU). The latter is the only Treaty provision mentioned in the Explanations to Art. 38 Charter. Interestingly, the A.G. seemed to adopt a restrictive interpretation of Art. 52(5) Charter, because he only mentioned the possibility of 
Directive in the light of Article 38 was, however, in this case not possible according to the both the Advocate General and the Court, because this would result in a contra legem interpretation, considering that the Directive does not expressly provide for a right for consumer protection associations to intervene. The Court held that Article 38 'cannot, by itself, impose an interpretation of that directive which would express such a right'. ${ }^{169}$ It is unclear whether the Court would have reached a different conclusion, had Article 38 been formulated in a more specific way and more as a right in the sense of Article 52(5) Charter. ${ }^{170}$ In a subsequent case, Kušionová, the Court of Justice even seemed to imply that Article 38 Charter, which was referred to as a 'mandatory requirement' applicable to the implementation of Directive 93/13, can preclude national legislation. That is to say, the Court did not immediately dismiss the possibility of legality review when requested by a Slovak court, but only undertook the review without further reference to Article $38 .{ }^{171}$

\section{Article 26: Glatzel}

It was in Glatzel that the Court of Justice expressed itself for the first time on Article 51(1) and Article 52(5) of the Charter. In this case, the Fifth Chamber of the Court issued a preliminary ruling on the request of a German court about the compatibility with the Charter of Annex III to Directive 2006/126/EC (amended by Directive 2009/113/EC) laying down minimum standards relating to the physical fitness to drive a motor vehicle as regards visual acuity. The German court asked the European Court of Justice whether those physical conditions for drivers constitute discrimination on the grounds of disability and, hence, violate the principle of equal treatment (Article 20 of the Charter), more specifically, the principle of non-discrimination on the grounds of disability (Article 21(1)) as well as the principle of integrating persons with disabilities (Article 26). ${ }^{172}$ The Court

interpreting and legality review of 'Union acts' and omitted any reference to 'acts of Member States when they are implementing Union law'; A.G. Wahl, supra n. 164, para 66. M. De Mol, De directe werking van de grondrechten van de Europese Unie [The direct effect of the fundamental rights of the European Union] (Wolf 2014) p. 51.

${ }^{169}$ Pohotovost, supra n. 6, para 52. A.G. Wahl, supra n. 164, para 67.

${ }^{170}$ What militates against this possibility is that the ECJ came to the same finding as regards Article 47 Charter, which is formulated as an individual entitlement. Pohotovost, supra n. 6, para 53.

${ }^{171}$ The ECJ eventually determined that the Directive does not preclude national legislation allowing the recovery of debts based on potentially unfair contractual terms by the extrajudicial enforcement of a charge on immovable property. Note that it is difficult to construe this Slovak law as an act implementing a principle (Art. 38 Charter) within the meaning of Art. 52(5) Charter. ECJ 10 September 2014, Case C-34/13, Monika Kušionová v SMART capital a.s., para 45-47.

${ }^{172}$ Art. 26 stipulates: 'The Union recognises and respects the right of persons with disabilities to benefit from measures designed to ensure their independence, social and occupational integration and participation in the life of the community.' 
of Justice eventually concluded that it did not have sufficient information to conclude that the Annex is invalid, yet it did offer some considerations as regards the character of these provisions that are of relevance for the purposes of the present article.

The Court of Justice first thoroughly examined the compatibility of Annex III with Article 21(1) of the Charter. After this quite extensive review, the Court performed another test of the compatibility of the Annex with Article 26. The Court thereby labeled Article 26 of the Charter as a principle. It primarily did so on the basis of the Explanations to the Charter, to which it made a passing reference. ${ }^{173}$ The Court also looked at the wording of the provision and it mentioned that Article 26 'does not require the EU legislature to adopt any specific measure' and that 'in order for that article to be fully effective, it must be given more specific expression in EU law or national law'. ${ }^{174}$ As in $A M S$, the Court thereby used the 'concretisation argument' as a decisive criterion.

Apparently, the Court found it necessary to emphasise the difference in nature of Articles 26 and Article 21(1), the first, other than the second, not being a 'right', but a principle. This is remarkable, because in the earlier cases of Dominguez and $A M S$ it chose to avoid this matter and Advocate General Bot did not at all reflect on the (principled) nature of Article 26. Moreover, the Court could easily have avoided pronouncing itself on the nature of Article 26 by examining the validity of Annex III with Articles 21(1) and 26 in an integrated way, as Advocate General Bot had done in his Opinion. ${ }^{175}$ Alternatively, the Court could have tested the validity against Article 21(1) and could have applied the same reasoning mutatis mutandis to its review of Article 26. Such possibilities of avoidance notwithstanding, now that the Court had decided to confront the question of applicability of Article 26 head-on, it could hardly have come to a different conclusion as to the nature of this provision than that which it eventually reached, since the text of the Explanations explicitly mention Article 26 as an example of a principle. $^{176}$

It is also interesting to examine what implications the Court drew from its determination that Article 26 is a principle. Firstly, the Court adopted a narrow and literal reading of Article 52(5) which limits judicial review to measures implementing a principle, as discussed above. The Court held that 'reliance on Article 26 [...] before the court is allowed for the interpretation and review of the legality of legislative acts of the European Union which implement the principle laid down in that article, namely the integration of persons with disabilities'

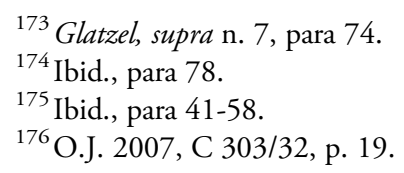


(emphasis added). ${ }^{177}$ Note that this interpretation is more restrictive than the Court's earlier approach in Kamberaj and Kušionová where judicial review was not limited to legislative acts 'implementing' a Charter principle. ${ }^{178}$ The Court subsequently went on to consider whether Directive 2006/126 is a legislative act that implements the principle of Article 26. It held that in so far as Directive 2006/126 is a legislative act of the European Union implementing the principle contained in Article 26 of the Charter, the latter provision is intended to be applied to the case in the main proceedings. ${ }^{179}$ Interestingly, the Dutch- and German-language versions of the judgment are formulated in more unconditional terms. Instead of using the more tentative 'in so far' they start with 'since' and thus imply that the Court of Justice is of the opinion that the Directive is an act implementing the principle in Article 26. ${ }^{180}$ This, however, suggests a wide notion of implementation, because it is difficult to see how Directive 2006/126 on driving licenses can be really seen as implementing the principle of Article $26 .{ }^{181}$ Thus, on the one hand, the Court of Justice can be criticised for adopting a restrictive reading by limited review to acts implementing a Charter principle. On the other hand, the Court can be reprehended for casting the net too wide as to what constitutes an implementing act.

Secondly, the Court confirmed that Article 26 'cannot itself confer on individuals a subjective right which they may invoke as such'. ${ }^{182}$ The Court was, however, silent on the broader role of principles as standard for legal review or tools of interpretation. Although it paraphrased Article 52(5), which stipulates that principles can be used as an interpretational tool or legality review, the Court did not acknowledge that principles can have a judicial function beyond this traditional narrow understanding of direct effect on the basis of Article 52(5). It has been shown above that while principles indeed cannot act as a 'sword', they can certainly act as a shield and offer protection against conflicting EU or national norms. This means that when a litigant has standing on the basis of another ground than the principle, a judge can strike down a legislative or executive act on the basis of a principle in the Charter. The Court unfortunately did not reflect on this possibility. By only conducting a review of the validity of Annex III with Article 21(1) and not Article 26, the Court seems to emphasise that principles cannot be used in judicial review at all.

${ }^{177}$ Glatzel, supra n. 7, para 74.

${ }^{178}$ Text to n. 132 and 171 supra. See also Cruz-Villalón, supra n. 161-162 and the text to n. 96-110 supra.

${ }^{179}$ Ibid., para 76.

${ }^{180}$ Respectively 'aangezien' and 'da'.

${ }^{181}$ Directive 2006/126 does, however, refer to disabled persons in recital 14, Art. 4(5), 5(2), 6(4)

(a) and Annex III.

${ }^{182}$ Glatzel, supra n. 7, para 78. 
Hence, in Glatzel the Court of Justice for the first time paid close attention to the distinction between rights and principles and the nature of Article 26 as containing a principle. The Court should be applauded for being explicit about this, although unfortunately it did not provide much guidance on the exact role of principles in judicial review and adopted a restrictive interpretation of the measures which can be reviewed.

\section{Conclusion}

This article examined the role of principles in the case law of the European Court of Justice, focusing on two specific issues: firstly, the extent to which a distinction is made between rights and principles and the criteria used to make such a distinction, and, secondly, the implications of this (lack of) distinction for judicial review.

Because the drafters of the Charter could not achieve consensus on the nature of each provision of the Charter, they decided to leave this matter for the Court to decide upon. The cases discussed above show that the Court of Justice has so far not taken on this task with much enthusiasm, nor with a very consistent approach. The Court only very recently, in Glatzel, referred to Articles 51(1) and 52(5) and a Charter provision as containing a principle. Before that, the Court remained silent on the distinction between rights and principles. Its judgment in Glatzel - and indirectly also AMS, where the Court framed the matter in terms of (horizontal) direct effect ${ }^{183}$ - as well as the Opinions of the Advocate General in Dominguez, AMS and Pohotovost provide some clarity as to the criteria (which could be) used to make such a distinction. Table 1 summarises the main findings and shows that the first and second criteria discussed above, dealing respectively with the wording and necessity of concretisation, have been used most frequently. In Glatzel and $A M S$ the Court of Justice primarily looked at the degree of concretisation required by a Charter provision, whereby the wording of the provision was used as the starting point. Its conclusions in Glatzel that Article 26 contains a principle and in AMS that Article 27 does not have direct effect, were based on the argument that for these article 'to be fully effective, [they] must be given more specific expression in EU law or national law'.

The Court of Justice has paid even less attention to the second question, of what role Charter principles can have in judicial review and how they can be 'judicially cognisable' in the sense of the final sentence of Article 52(5).

${ }^{183}$ This, and the fact that the criteria used to make a distinction between Charter rights and principles closely resemble the conditions for direct effect, implies that this distinction is largely a 'modern' and adapted version of the doctrine of direct effect. Robin-Olivier, supra n 132, p. 169. See text to $\mathrm{n} .67$ and 102 supra and n. 188 infra. 


\section{Implication for judicial review}

- Direct effect/ entitlement (right)

- Standard of legality (rights \& principles)

- Tool for interpretation (rights \& principles)

\section{ECJ}

A.G.

ECJ

A.G.

Dominguez Article 31(2)

'particularly important principle of EU social law' (Charter not cited

ght [criteria: wording (individual entitlement) \& systemic argument; proximity to Articles 28-29]

Heimann Article 31(2)

'particularly important principle of EU social law'

$\mathrm{X}$ [no Opinion]

$$
\text { - }
$$

AMS Article 27

Silent on distinction 52(5). Excluded direct effect [criteria: wording $\&$ necessity of concretisation]

Pohotovost Article 38

Principle [criteria: wording \& necessity of concretisation]
Principle [criteria: wording, margin of discretion \& systemic argument: Chapter IV]

\section{Principle [criteria: wording (no} individual entitlement)]
Used as standard of legality

Used as tool for interpretation

Determined that Art. 27 is no subjective right

Used as tool for interpretation

- Determined that no subjective right

- Silent on specifics review; but stated that review is limited to measures implementing principles

Used as standard of legality

$\mathrm{X}$ [no Opinion]

Used as tool for interpretation

— Determined that Art. 27 can be standard of legality

- Review not limited to measures implementing principles

Used as tool for interpretation

Used as standard of legality 
In Glatzel, the Court adopted a restrictive interpretation of Article 52(5) by limiting judicial review to measures implementing a certain Charter principle. While the Court held that Article 26 as a principle 'cannot itself confer on individuals a subjective right which they may invoke as such', it did not pay attention to the role of principles as standard for legal review or tools of interpretation. However, in other cases the Court was not concerned with the implications of Article 52(5) and simply applied Charter provisions which are arguably principles. ${ }^{184}$ In Heimann, it used a principle of social EU law as a standard of legality. In Kamberaj and Pohotovost, the Court did apply Article 34(3) and Article 38 - which are generally seen as principles - as interpretational tools to arrive at a consistent interpretation. This interpretational function was also proposed with respect to the seeming principles of Articles 34, 35 and 37 in subsequent cases by an Adovocate General or the Commission. ${ }^{185}$

What could explain the Court's earlier reluctance to make a pronouncement on the distinction until Glatzel as well as its current reluctance to address the distinction's implications for judicial review? One possibility could be that the Court of Justice is still in the 'start-up phase' with respect to the Charter since the entry into force of the Lisbon Treaty in 2009. Several scholars noted that in the five years since, the Court has not really been consistent in its application of the Charter. ${ }^{186}$ Another explanation would be that the silence of the Court of Justice is a deliberate tactic. As was noted by Pech, the Court's reluctance 'may simply reflect the pragmatic wish - albeit one which cannot be confessed - to spare itself the dreadful task of making sense of the Charter's general provisions, which aim to constrain its interpretation and scope of application. ${ }^{187}$ Several elements might

\footnotetext{
${ }^{184}$ This also reflects the broader trend that the ECJ not always examines whether the conditions for direct effect are fulfilled, but just applies an EU provision to the case. Othmar Michaeler, supra n. 106. De Witte, supra n. 101, p. 332. Robin-Olivier, supra n. 132, p. 174-175.

${ }^{185}$ A.G. Cruz Villalón,, supra n. 136. In Petru, the Commission (and the applicant) proposed an interpretation of Art. 22 Regulation 1408/17 in conformity with Art. 35 Charter dealing with health care; A.G. Cruz Villalón, Opinion 19 June 2014, Case C-268/13, Elena Petru, para 12 and 14. See also A.G. Bot held that the achievement of a high level of environmental protection, as laid down in - amongst others - Article 37 Charter, is 'an imperative requirement' which enjoys 'pre-eminence over other considerations'; A.G. Bot, Opinion 8 May 2013, Joined Cases C-204/12 to C-208/12, Essent Belgium NV, para 95-96.

${ }^{186}$ De Búrca, for instance, noted the ECJ's lack of human rights experience and expertise; G. De Búrca, 'After the EU Charter of Fundamental Rights: the Court of Justice as a human rights adjudicator?', 20 MJ (2013) p. 168 at p. 170-171. Pech, supra n. 118. S. Iglesias Sánchez, 'The Court and the Charter: the impact of the entry into force of the Lisbon Treaty on the ECJ's approach to fundamental rights', 49 CML Rev. (2012) p. 1565 at p. 1568. S. Douglas-Scott, 'The European Union and human rights after the Treaty of Lisbon', 11 HRLR 4 (2011) p. 645 at p. 678-679.

${ }^{187}$ Pech, supra n. 118, 1861. Iglesias Sánchez, supra n. 186, 1609. Lazzerini referred to the fear to open the 'Pandora's box of the rights-principles distinction'; Lazzerini, supra n. 46, p. 931.
} 
explain this 'principled silence' with respect to Article 52(5) as well, at least in the judgments before Glatzel. Firstly, it could be that the heated opposition of several states to justiciable rights, most notably of the UK, contribute to the Court's unwillingness to make solid use of Charter principles. It thus seems that the shadow of Protocol 30 stipulating that 'nothing in Title IV of the Charter creates justiciable rights' weighs on the Court. Secondly, some of the judges in the Court of Justice might be of the opinion that the distinction between rights and principles is irrelevant or impracticable. Rather than including a new terminology and categories in the EU legal order, the Court might prefer to stick to its earlier approach and case law. This was also suggested by Prechal, a judge at the Court of Justice, who questioned the distinction between right and principles and argued that the more relevant question is whether the provision of the Charter fulfils the requirement for direct effect; whether it is sufficiently precise and unconditional. She argued that a separate assessment as to whether an invoked Charter provision is a right or principle in the sense of Article 52(5) 'seems redundant'. ${ }^{188}$ Elsewhere, Prechal, who was one of the judges deciding $A M S$, suggested that the $A M S$ judgment should be read in this light. ${ }^{189}$ This explanation seems justified in the light of the similar dynamics, observed above, that underlie the doctrine of (in)direct effect and the distinction between Charter rights and principles. ${ }^{190}$

The Glatzel judgment, however, does not match this explanation, because the Fifth Chamber of the Court of Justice found it necessary to frame the issue in terms of rights and principles. ${ }^{191}$ The Court thus left its 'principled silence' behind in Glatzel and accepted the challenge of clarifying the difference between rights and principles and the consequences of that difference. Although Glatzel was a logical first step in the sense that it acknowledged that there are differences between rights and principles in terms of judicial review, it did not fully spell out all the implications of Article 52(5), thereby still leaving a considerable amount of uncertainty. It remains to be seen whether Glatzel will be the exception or whether it will be a prelude to a new line of cases which explicitly engage with the distinction. If the Court chooses to continue along the Glatzel path, it is to be

\footnotetext{
${ }^{188}$ Peers and Prechal, supra n. 43, para 52.190.

${ }^{189}$ She made these statements during a seminar on the EU Charter. 'Verslag NJCM-Seminar. Het EU-Handvest. Van toenemende betekenis voor EU-Grondrechtenbescherming?' [Report of the NJCM Seminar. The EU Charter. Of increasing significance for EU fundamental rights protection?], 39 NTM/NJCM-Bulletin (2014) p. 121.

${ }^{190}$ See n. 183 supra.

${ }^{191}$ One explanation for this difference might be that Prechal was not a judge in Glatzel. Judges in Glatzel were, amongst others, Von Danwitz and Rosas, who both have written on the difference between rights and principles in terms of possibilities for judicial review. Von Danwitz, supra n. 68. A. Rosas and L. Armati, EU Constitutional Law. An introduction (Hart 2012) p. 178-179.
} 
hoped that it provides more detailed criteria to determine whether a provision is a right or principle. Further clarification is also desirable as regards the consequences of the distinction between rights and principles for the type of judicial review that is possible. That would prevent the Court from being criticised for an arbitrary or inconsistent approach. 